\title{
Study of temperature logs of linseed, corn and chia seeds for the treatment of joint pain and inflammation
}

\section{Estudio de los registros de temperatura de las semillas de lino, maíz y chía para el tratamiento del dolor y la inflamación de las articulaciones}

DOI: $10.46932 / \mathrm{sfjdv2n5-127}$

Received in: Oct 1st, 2021

Accepted in: Dec 30th, 2021

\begin{abstract}
Dr. Juan José Piña Castillo
$\mathrm{PhD}$ in Education from the Universidad Contemporánea de las Américas, Master of Science in Mechanical Engineering with a specialty in thermofluids, Bachelor of Science in Mechanical Engineering both from the Universidad Michoacana de San Nicolás de Hidalgo, currently Professor of the Faculty of Mechanical Engineering, Professor of the Bachelor of Mechatronics Engineering and Professor in the Bachelor of Energy and Sustainability all at the Universidad Michoacana de San

Nicolás de Hidalgo.

E-mail: jpina@umich.mx

\section{Renato González Bernal}

M. en C.

Master of Science in Mechanical Engineering specializing in thermofluids, Bachelor of Science in Mechanical Engineering all from the Universidad Michoacana de San Nicolás de Hidalgo, currently

Professor of the Faculty of Mechanical Engineering, Professor of the Bachelor of Mechatronics Engineering and Professor in the Bachelor of Energy and Sustainability all at the Universidad Michoacana de San Nicolás de Hidalgo.

E-mail: regonzalez@umich.mx
\end{abstract}

\section{Jesús Cirilo Trujillo Jiménez}

M. en C.

Master of Science in Mechanical Engineering specializing in thermofluids, Bachelor of Science in Mechanical Engineering all from the Universidad Michoacana de San Nicolás de Hidalgo, currently

Professor of the Faculty of Mechanical Engineering, Professor of the Bachelor of Mechatronics Engineering and Professor in the Bachelor of Energy and Sustainability all at the Universidad Michoacana de San Nicolás de Hidalgo.

E-mail: jcirilo@umich.mx

Mauricio Piña Solís

Faculty of Chemical Engineering; Universidad Michoacana de San Nicolás de Hidalgo (student) E-mail: 1831534g@umich.mx

\begin{abstract}
Thermal energy storage in the form of heat provides transient relief in inflammatory and traumatic, subacute and chronic disorders such as: sprains, muscle strains, muscle spasms, low back pain, cervical injuries, various forms of arthritis, arthralgia, neuralgia. Heat increases blood flow and connective tissue extensibility; it also decreases joint stiffness, pain and muscle spasm and helps relieve inflammation. The application of heat can be superficial and the intensity or duration of the physiological effects depends mainly on the temperature of the tissue, the rate of temperature elevation and the area treated. In this work
\end{abstract}


a comparison of the capacity to absorb and contain sensible heat using a combination of linseed, corn and chia seeds in water is made in order to identify which combination is able to retain heat longer and to take advantage of this characteristic in the treatment of pain and inflammation.

Keywords: Thermal energy, temperature, thermal energy.

\section{RESUMEN}

El almacenamiento de energía térmica en forma de calor proporciona un alivio transitorio en trastornos inflamatorios y traumáticos, subagudos y crónicos como: esguinces, distensiones musculares, espasmos musculares, lumbalgias, lesiones cervicales, diversas formas de artritis, artralgias, neuralgias. El calor aumenta el flujo sanguíneo y la extensibilidad del tejido conectivo; también disminuye la rigidez articular, el dolor y el espasmo muscular y ayuda a aliviar la inflamación. La aplicación de calor puede ser superficial y la intensidad o duración de los efectos fisiológicos depende principalmente de la temperatura del tejido, del ritmo de elevación de la temperatura y de la zona tratada. En este trabajo se realiza una comparación de la capacidad de absorber y contener el calor sensible utilizando una combinación de semillas de lino, maíz y chía en agua, con el fin de identificar qué combinación es capaz de retener el calor durante más tiempo y aprovechar esta característica en el tratamiento del dolor y la inflamación.

Palabras clave: Energía térmica, temperatura, energía térmica.

\section{INTRODUCTION}

Low back pain is a frequent problem that affects 80 out of every 100 people and increases in those who suffer from obesity. According to the International Society for the Study of the Lumbar Spine, low back pain is defined as "a painful syndrome localized in the lumbar region (lower back) with eventual irradiation to the gluteal region, the hips or the distal part of the abdomen". In the acute state, this syndrome is aggravated by all movements and in the chronic form only by certain movements of the lumbar spine.According to the World Health Organization (WHO) it is the first cause of consultation worldwide (70\%) where only $4 \%$ require surgery. When low back pain is not adequately treated, it can cause frequent relapses and prevent the person from returning to his/her daily activities, causing prolonged periods of disability.Low back pain presents costs associated with work incapacity; approximately $30 \%$ of low back pain carriers in Mexico require incapacity. In the United Kingdom, absenteeism associated with this disease is $13 \%$, while in the United States it is $33 \%$. leads to pain and loss of function primarily in the knees and hips, affects $9.6 \%$ of men and $18 \%$ of women aged $>60$ years. Increases in life expectancy and ageing populations are expected to make osteoarthritis the fourth leading cause of disability by the year 2020.This demonstrates the importance of having specific national statistics, since it is possible that working conditions modify this variable.

Some risk factors for low back pain are:

Genetic predisposition, Standing for a long time, Carrying heavy things, Overweight or obesity, Sedentary lifestyle, Work stress, Inadequate postures and Unsafe acts in physical activities.Physical load 
and psychosocial factors are risk factors that were associated with the incidence and prevalence of low back pain.

Classification of acute back pain

The patient with acute backache should be assessed as having:

- simple back pain

- nerve root pain

- possible serious spinal pathology.

This distinction is made on clinical grounds without the need for investigations.

The treatments recommended in general measures for the relief of low back pain are:

Rest: It should only be indicated in the first 48 hours if the pain is disabling. There is sufficient scientific evidence that prolonged rest does not improve the prognosis, but rather favors the loss of physical fitness.Education: Includes information on the treatment process and its usual evolution towards resolution in a short period of time.Suppression of risk factors and activity modification. Suspend those activities that increase pain, perform your daily activities of less effort and do not fall into inactivity.Physical treatments: Manual massage, thermotherapy, electrotherapy, traction, manipulations, and exercises (stretching and strengthening sessions).Pharmacological treatment: Non-steroidal antiinflammatory drugs, analgesics, muscle relaxants, corticosteroids. Heat Treatment: Heat provides transient relief in subacute and chronic inflammatory and traumatic disorders.Heat energy storage is defined as the temporary storage of concentrated energy at high temperatures. Thermal energy storage can mitigate environmental impacts and facilitate more efficient energy systems, featuring a longer thermal storage period, typically three or more months. This can contribute significantly to meeting society's needs in systems requiring heat transfer, such as the treatment of pain and inflammation. At present, linseed, corn and chia seeds are not in wide demand in society, so they can be acquired at low cost.Sensible heat. It is the heat energy that supplied to a body or an object, causes it to increase its temperature without affecting its molecular structure and therefore its phase. The conductivity of the material is of importance, since it determines the capacity to absorb and release the heat contained in it.

Background

Thermal energy storage can be defined as a technology in which thermal energy is stored by heating or cooling a storage medium so that this energy can be used for other applications at a later time. The thermal behavior of materials is a broader topic, more directly related to their general thermal properties, than to thermal effects of specific interest; for example, heat transfer processes, or the fact that when energy is added to a material, it heats up, are general thermal behaviors of matter, which are not usually included in the analysis of thermal effects. Most of the time, thermal effects are understood to focus only on materials (understood as solid materials), and to deal with the effects of an uncomfortable 
(cold or hot) working temperature on some material properties, including the thermal processes used to produce, change or remove those materials. Sometimes also referred to as "the effect of heat on materials," i.e., the effect of heating to increase internal energy. Of course, the effects of cooling are also relevant.

The traditional thermal effects are:

- Phase change, basically melting and boiling.

- Glass transition temperature.

- Dimensional change, basically thermal expansion.

- Elasto-plastic changes, due to thermal stresses.

- Brittle/ductile transition temperature.

- Chemical change, decomposition, oxidation, ignition.

- Other physical changes such as drying, segregation, outgassing, color change, etc.

- Thermal effects due to non-thermal causes: frictional heating, electrical heating, chemical heating, nuclear heating.

Small temperature changes can lead to the storage of large amounts of heat. If the stored energy must be kept for a long time before use, or be transported to a place far away from the original thermal source, thermochemical storage is the best solution.

Objectives

To analyze the temperature records of three types of seeds (linseed, corn and chia) to relate them to efficient thermal energy storage and their application in pain and inflammation treatments.

Method

For the present investigation a metallic container was used which was filled with one liter of water, the container was exposed to fire until the water reached its boiling point, then the heat source was removed and with the help of a thermocouple water temperature readings were taken every three minutes until it reached room temperature.

Table 1. Shows the ambient temperature conditions and type of thermocouple used.

\begin{tabular}{|l|l|}
\hline Ambient temperature & Thermocouple \\
\hline $25^{\circ} \mathrm{C}$ & Type $\mathrm{K}$ \\
\hline
\end{tabular}

In order to obtain the water cooling curve, the boiling temperature was $93^{\circ} \mathrm{C}$ and the ambient temperature $25^{\circ} \mathrm{C}$. 
Figure 1 shows the record of the cooling temperature, showing that the water reaches room temperature at 81 minutes. This will serve as a reference for the final analysis.

Figure 1. Water cooling temperature record.

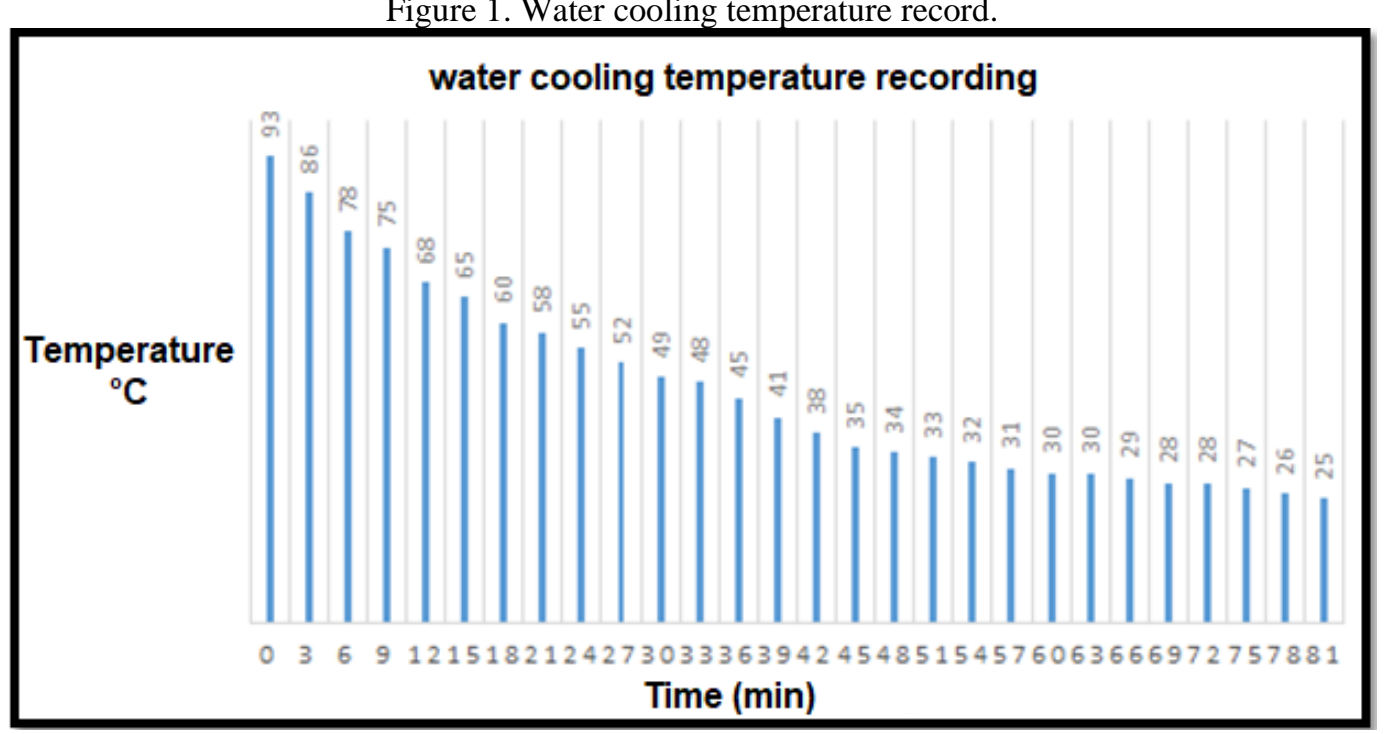

In the case of the water mixtures with the three types of seeds, 150 grams of each species were added to the water and the mixture was brought to boiling point, obtaining the following results.

Results

From the records obtained, the cooling data were obtained, recording on the vertical axis the temperature in degrees Celsius and on the horizontal axis the time expressed in minutes, for each case.

Figure 2. Shows the cooling temperature record, showing that the water reaches room temperature at 81 minutes, while the water-linseed mixture reaches room temperature at 96 minutes, with a difference of 15 minutes until thermal equilibrium is reached.

Figure 2. Record of cooling temperatures of water vs flaxseed.

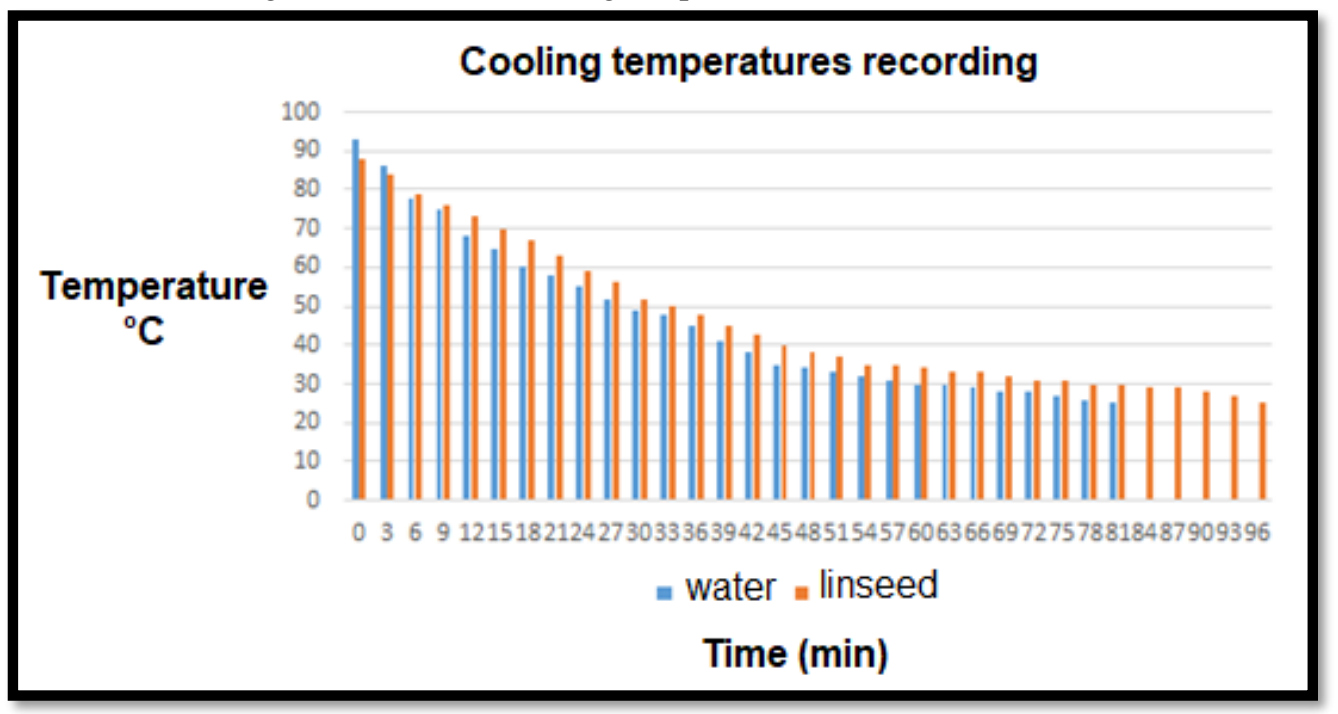


Figure 3 shows the cooling temperature record, showing that water reaches room temperature at 81 minutes, while the water-corn mixture reaches room temperature at 114 minutes, with a difference of 33 minutes until thermal equilibrium is reached.

Figure 3. Record of cooling temperatures of water vs corn.

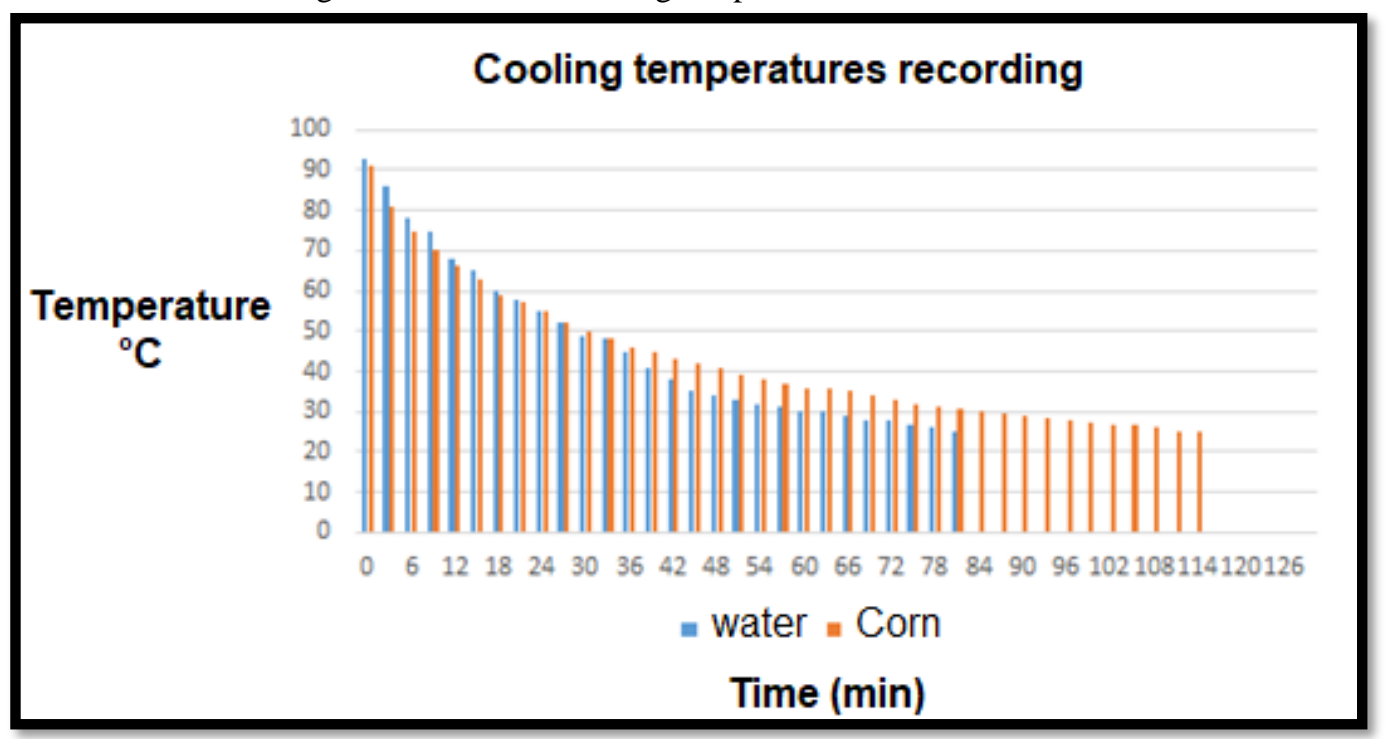

Figure 4 shows the cooling temperature record, showing that the water reaches room temperature at 81 minutes, while the water and chia mixture reaches room temperature at 129 minutes, with a difference of 48 minutes until thermal equilibrium is reached.

Figure 4. Record of cooling temperatures of water vs. chia.

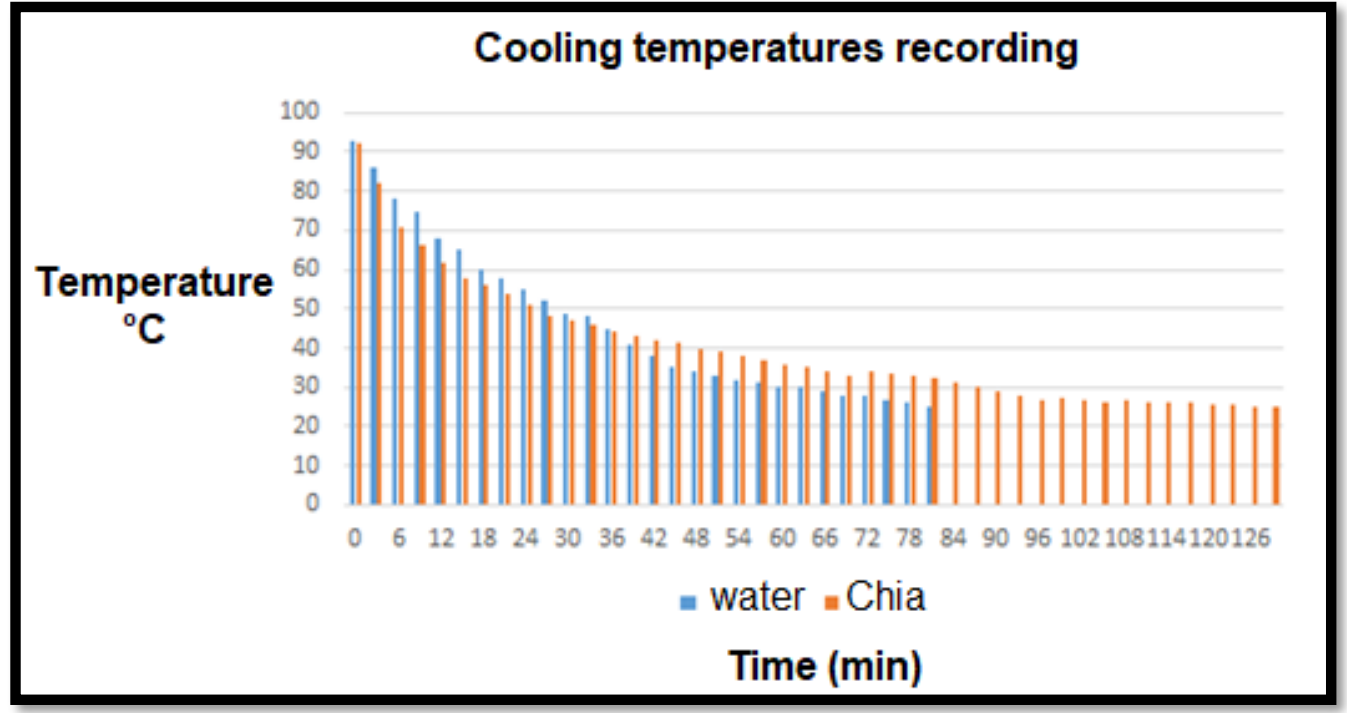

Figure 5 shows that in the case of water there are large temperature jumps and then the heat transfer slows down and the water-chia mixture maintains a more constant heat transfer rate. 
Figure 5. Comparison of the temperature record.

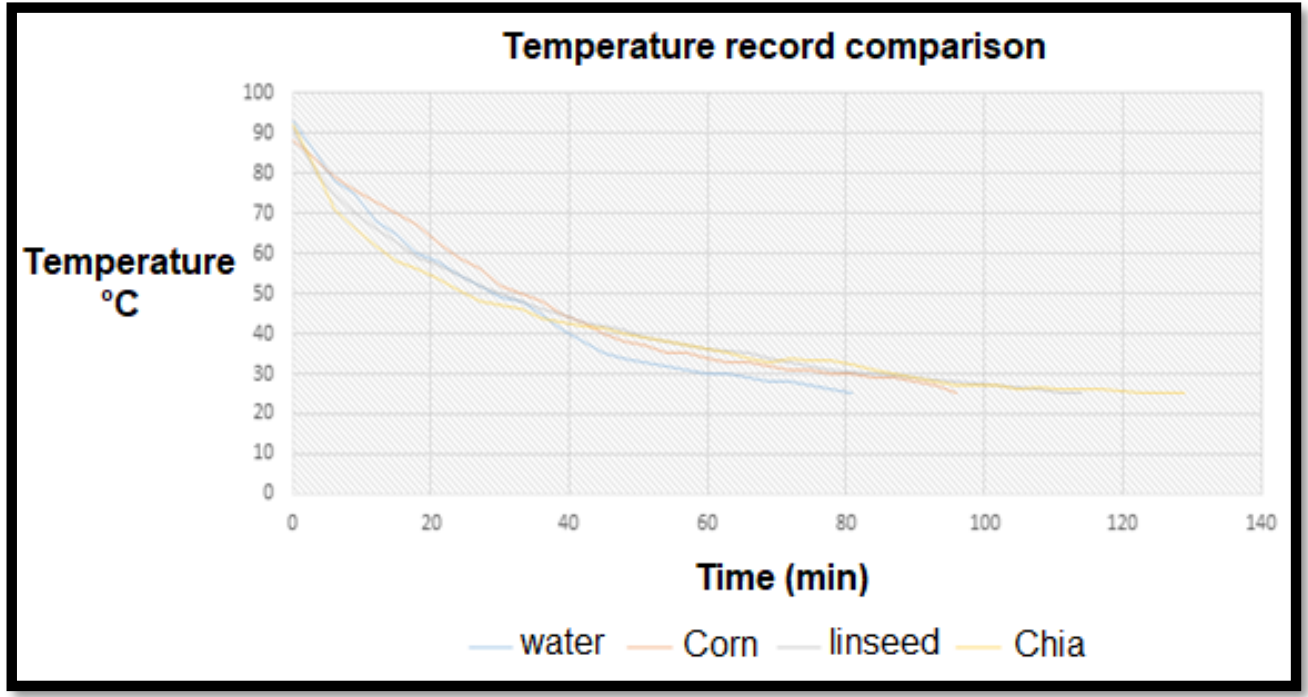

In the case of the mixture of water with chia, it is observed that it is the mixture that retains heat longer. Based on the information, the following data tables are presented.

Table 2. Temperature measurements for common water

\begin{tabular}{lrc} 
Measurement & Temperature $\left({ }^{\circ} \mathrm{C}\right)$ & $\frac{d T}{d t}$ \\
1 & 92 & - \\
2 & 82 & 0.0556 \\
3 & 71 & 0.0611 \\
4 & 66 & 0.0277 \\
5 & 62 & 0.0222 \\
6 & 58 & 0.0222 \\
7 & 56 & 0.0111 \\
8 & 54 & 0.0111 \\
9 & 51 & 0.0167 \\
10 & 48 & 0.0167 \\
11 & 47 & 0.0056 \\
12 & 46 & 0.0056 \\
13 & 44 & 0.0111 \\
\hline
\end{tabular}

Table 3. Temperature measurements for water/chia mixture

\begin{tabular}{lrr} 
Measurement & Temperature $\left({ }^{\circ} \mathrm{C}\right)$ & $\frac{d T}{d t}$ \\
1 & 90 & - \\
2 & 88 & 0.0111 \\
3 & 86 & 0.0111 \\
4 & 84 & 0.0111 \\
5 & 84 & 0 \\
6 & 82 & 0.0111 \\
7 & 82 & 0 \\
8 & 79 & 0.0167 \\
9 & 78 & 0.0056 \\
10 & 78 & 0 \\
11 & 76 & 0.0111 \\
12 & 76 & 0 \\
13 & 74 & 0.0111 \\
\hline
\end{tabular}




\section{ANALYSIS OF RESULTS}

From the measurements taken and the tables made, graphs were made showing temperature versus time.

In Figure 6, it is possible to observe how chia maintained a higher temperature compared to the temperature drop in the case of common water.

As the temperature difference between the two substances is significant, since at time 13 there is a $\Delta \mathrm{T}=30^{\circ} \mathrm{C}$ between the two substances, having elapsed the same amount of time.

Figure 6. T-t graph of heat release for both cases.

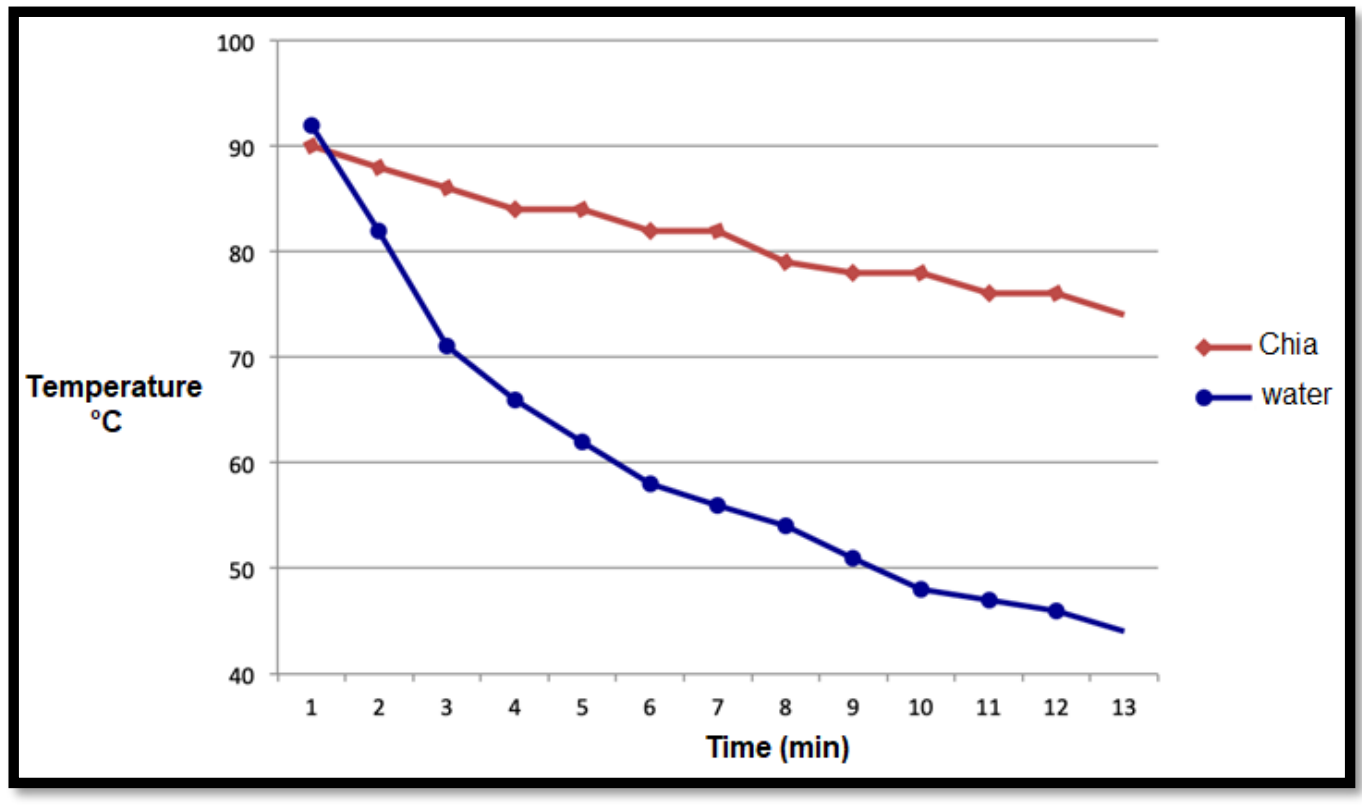

Figure 7 shows the $\frac{d T}{d t}-t$ graph, which shows the speed with which the temperature dropped in both substances.

In the case of common water, it can be seen how in the first measurement intervals the temperature jumps were very large until the heat transfer process slowed down a little.

On the contrary, according to the results shown in the graph, the mixture of water and chia seeds started with a constant temperature change and then there were no changes in its temperature. 
Figure 7. $\frac{d T}{d t}-t$ graph.

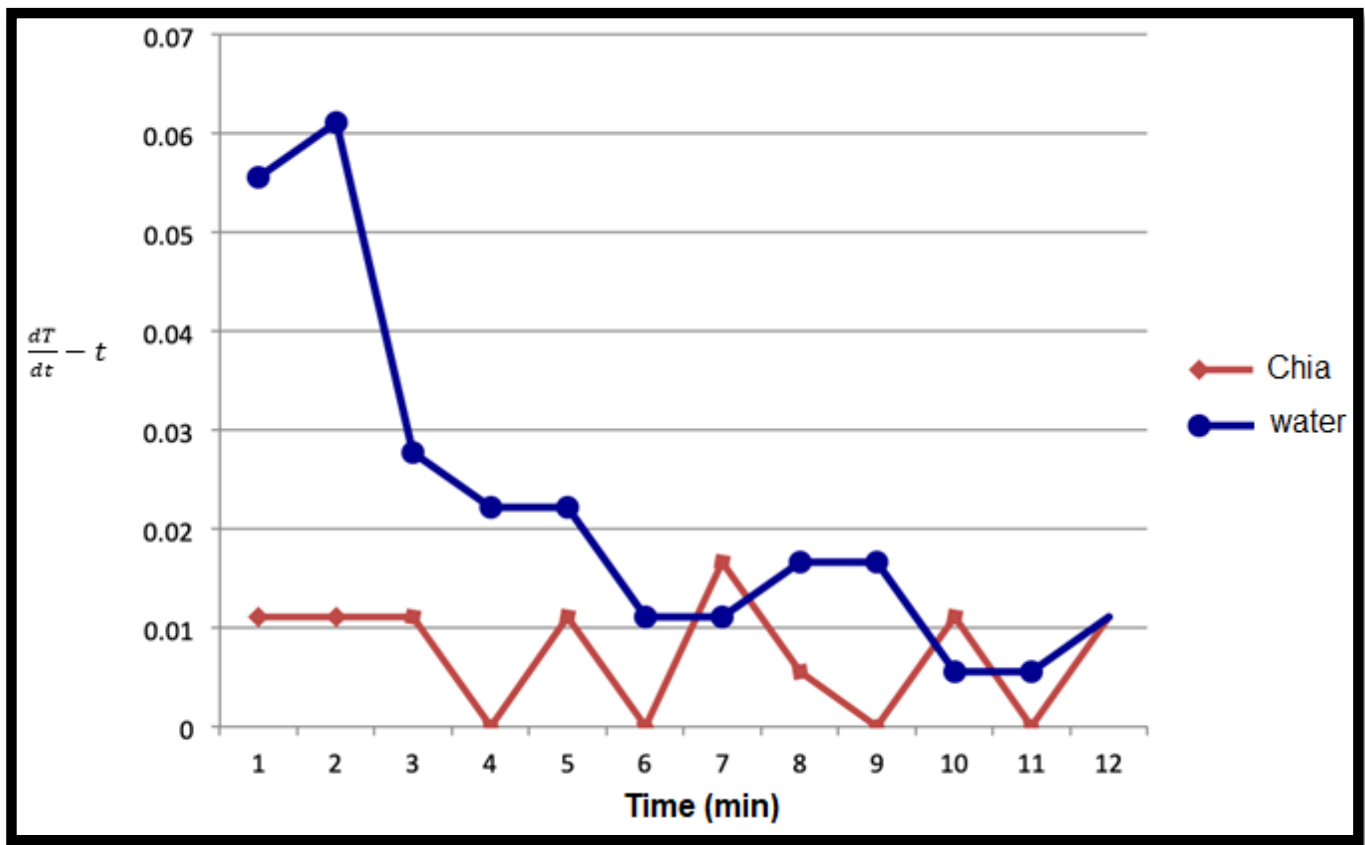

\section{CONCLUSIONS}

According to the results obtained and their interpretation, it can be concluded that chia is a good heat storage material when compared to water, since it has a greater heat retention capacity because its heat loss rate is lower than that of water and because it has a great difference in temperature at the same time.

This mixture should be considered for heat therapy to treat low back pain and inflammation, which dilates blood vessels and promotes blood flow. This helps to 'open up' the sore muscles and relaxes them. Thus, circulation improves and provides more oxygen and nutrients to the muscles. 


\section{REFERENCES}

Paksoy, H. O. (2005). Thermal Energy Storage for Sustainable Energy Consumption. Izmir, Turquía: NATO Science Series.

Jayson MI. Acute back pain. Clin Med 2001;1:188-89 [Crossref], [PubMed], [Web of Science ®], [Google Scholar]

Woolf AD, Pfleger B. Burden of major musculoskeletal conditions. Bull World Health Organ 2003;81:646-56 [PubMed], [Web of Science ®], [Google Scholar]

NINDS. Pain: hope through research. 2009. Available at: http://www.ninds.nih.gov [Last accessed 11 June 2009] [Google Scholar]

Lawrence RC, Felson DT, Helmick CG, et al. Estimates of the prevalence of arthritis and other rheumatic conditions in the United States. Part II. Arthritis Rheum 2008;58:26-35 [Crossref], [PubMed], [Web of Science ${ }^{\circledR}$ ], [Google Scholar]

Raspe H, Hueppe A, Neuhauser H. Back pain, a communicable disease?. Int J Epidemiol 2008;37:6974 [Crossref], [PubMed], [Web of Science ${ }^{\circledR}$ ], [Google Scholar]

Suka M, Yoshida K. Musculoskeletal pain in Japan: prevalence and interference with daily activities. Mod Rheumatol 2005;15:41-7 [Taylor \& Francis Online], [Google Scholar]

United States Bone and Joint Decade. USBJD Condition Kit: Low Back Pain. Scope of the Disease. 2007. Available at: www.usbjd.org/patients_public/index.cfm [Last accessed 11 June 2009] [Google Scholar]

Wenig CM, Schmidt CO, Kohlmann T, et al. Costs of back pain in Germany. Eur J Pain 2009;13:2806 [Crossref], [PubMed], [Web of Science $\left.{ }^{\circledR}\right]$, [Google Scholar]

Wynne-Jones G, Dunn KM, Main CJ. The impact of low back pain on work: a study in primary care consulters. Eur J Pain 2008;12:180-8 [Crossref], [PubMed], [Web of Science ${ }^{\circledR}$ ], [Google Scholar]

Canadian Chiropractic Association. Survey of Canadian Adults: Back Pain. 2003. Available at: http://www.ccachiro.org/client/cca/cca.nsf/object/Back+Pain/\$file/5360+back+pain.pdf [Last accessed 11 June 2009] [Google Scholar]

Walker BF, Muller R, Grant WD. Low back pain in Australian adults: the economic burden. Asia Pacific J Public Health 2003;15:79-87 [Crossref], [PubMed], [Google Scholar]

Licciardone JC. The epidemiology and medical management of low back pain during ambulatory medical care visits in the United States. Osteopath Med Prim Care 2008;2:11 [Crossref], [PubMed], [Google Scholar]

Kaiser Permanente. Controlling presenteeism. A healthy and productive workforce is the solution. 2009. Available at: https://brokernet.kp.org/wps/wcm/connect/a07c25804dea54bf5b9db7/TTHP_PresenteeismCA.pdf? MOD=AJPERES [Last accessed 6 June 2009] [Google Scholar] 
AAOS. Aching backs impact cost, disability. 2009. Available at: http://www.aaos.org/news/aaosnow/jan0/research6.asp9 [Last accessed 29 May 2009] [Google Scholar]

Atlas SJ, Deyo RA. Evaluating and managing acute low back pain in the primary care setting. J Gen Intern Med. 2001;16:120-31 [Crossref], [PubMed], [Web of Science ®], [Google Scholar]

Leboeuf-Yde C. Back pain - individual and genetic factors. J Electromyogr Kinesiol 2004;14:12933 [Crossref], [PubMed], [Web of Science ®], [Google Scholar]

Klineberg E, Mazanec D, Orr D, et al. Masquerade: medical causes of back pain. Cleve Clin J Med 2007;74:905-13 [Crossref], [PubMed], [Web of Science ®], [Google Scholar] 